Scientific Research \& Studies Center-Faculty of Science- Zagarig

University - Egypt

Biochemistry Letters

Journal home page:

\title{
Influenza virus A and B can induce apoptosis via intrinsic or extrinsic pathways and also via NF-kB.
}

\section{Ibrahim El-Sayed1, Khalid Bassiouny1, Aziz Nokaly2, Ahmed S. Abdelghaniz and Wael Roshdy3}

1-Genetic Engineering and Biotechnology Research Institute (GEBRI), Sadat University, Sadat city

2-Faculty of Medicine, Al Azhar University, Cairo

3-Central Public Health Laboratories (CPHL), Cairo

\begin{tabular}{ll}
\hline A R T I C L E I N F O & A B S T R A C T \\
\cline { 1 - 3 } Keyords: & Objectives
\end{tabular}

Influenza virus

Caspases

Apoptosis
Influenza viruses are able to cause annual epidemics and pandemics due to their mutation rates and reassortment capabilities leading to antigenic drifts and antigenic shifts.

To understand host response to influenza A and B viruses on A549, MDCK II cell lines at low and high MOIs, the effects of the viral infection were investigated. To identify virus host interplay, expression of MxA and caspases 3, caspases 7 and caspases 9, BAD, TNF $\alpha$ and $\operatorname{IkB} \alpha$ genes were measured in the cells supernatants. Methods Cell viability and apoptosis were evaluated by LDH measurement, DNA fragmentation, and florescent staining. The resulting data points to all viruses of studied strains induced extrinsic and intrinsic apoptosis, $\mathrm{H} 1 \mathrm{~N} 1$ and $\mathrm{H} 3 \mathrm{~N} 2$ respectively prefer initially enhances the intrinsic pathway, as determined by caspase 9 activity and INFB prefer intrinsic pathway according to caspase 8 activity in A549 cell line but also can choose extrinsic pathway as determined by caspase 9 activity MDCKII cells.

Results The result suggests a role for IFN response in the replication of influenza A and B virus that may provide some degree of host resistance in the early stages of infection. Our study also showed that the considerable MxA expression was found in influenza A and B virus, infected A549 and MDCK II cells at low dose of the virus. Conclusions The expression levels of survival downstream targets of $\mathrm{I} \kappa \mathrm{B}$ protein level, including pro-apoptotic BAD levels were studied throughout the infection periods cells to influenza A and B induced apoptosis signaling via intrinsic and extrinsic pathways in parallel, and the induction was associated with viral infection in a dose dependent manner. 


\section{INTRODUCTION}

Influenza virus A and B infection induce distinct apoptosis profiles, the differential biological effects of the influenza $A$ and $B$ viruses have been the focus of intense research [1]. Influenza A virus, a major cause of morbidity and mortality in humans, is primarily a pathogen of the upper respiratory tract its infection results in both respiratory effects and constitutional effects $[2,3]$. Influenza viruses are able to cause annual epidemics and pandemics due to their mutation rates and reassortment capabilities leading to antigenic drifts and antigenic shifts [4-6].

Influenza viruses belong to the Orthomyxoviridae family and are grouped into types (and subtypes), of which type A and B are the most relevant to humans $[7,8]$.

They are enveloped, negative single stranded RNA viruses with a segmented genome divided into 8 genes that code for 11 proteins [6], which not only act as viral components but also interact with the pathways of host infected cells, mainly to counteract the antiviral cell response and help the viral replication [9-11]. To date, up to 1023 interactions between viral and host proteins have already been described [6,9]. Apoptosis induced during influenza virus infection is a major contributing factor to cell death and tissue damage [12- 15].

All of the mammalian, as well as all of the avian, influenza viruses tested induce apoptosis in MDCK cells , which improve that apoptosis is a general mechanism by which influenza viruses kill cells and, therefore, that these viruses can be blocked by cellular inhibitors of apoptosis [12].

Studies with the 1918 pandemic virus in macaques showed that activation of the apoptotic pathway was a source of tissue damage during infection [16-18].

In mammalian cells, the apoptotic pathway can be divided into two signaling cascades: the extrinsic and the intrinsic apoptotic pathways [19].

The intrinsic apoptotic pathway acts through the mitochondria upon activation, and this signaling process is highly regulated by the Bcl-2 family of proteins, which consists of both anti-apoptotic and pro-apoptotic members that form a critical decision point within a common cell death signaling pathway [20].

The delicate balance between anti-apoptotic and pro-apoptotic protein activities dictates whether a cell will succumb to an apoptotic stimulus or not $[21,22]$.

Despite the increasing knowledge in the influenza virus host interactions, most of the published work focuses on influenza A viruses, leaving a gap in respect to influenza $\mathrm{B}$ virus host interactions [5, 23].

H3N2 viruses with high NA activities induced high levels of apoptosis $(83-94 \%)$ and infected $91-98 \%$ of cells, while H1N1 viruses with low NA activities were poor apoptosis inducers (11 $19 \%)$ and infected few $(15-21 \%)$ cells. The differences in \% infected cells reflected differences in haemagglutinin (HA) receptor binding affinity [24].

Bcl-2 and Bcl-xL are well known targets of the pro-apoptotic protein $\mathrm{Bcl}-2$ antagonist of cell death (BAD), which specifically blocks the activity of both anti-apoptotic factors $\mathrm{z}$ by forming heterodimeric complexes with either of the two proteins and displacing $\operatorname{Bax}[15,25,26]$.

One of its downstream targets is the IkB kinase (IKK), which once engaged leads to the activation of the transcription factor NF-kB. In fact, under resting conditions, NF-kB is sequestered in the cytoplasm through interaction with $\mathrm{IkB}$ protein that prevents NF-kB from entering the nucleus [27].

NF-kB sensitive pro-inflammatory miRNA with a relatively short half-life of about $2 \mathrm{~h}$ in the human CNS [23, 28].

Following NF-kB activating stimuli, IKK is activated and phosphorylates $\mathrm{IkB}$, thus promoting nuclear translocation of NF-kB to induce transcriptional activation of survival proteins, including Bcl-XL, Bcl-2 and X-linked inhibitor of apoptosis protein (XIAP) $[29,30]$.

Importantly NF- $\mathrm{kB}$ activation is usually terminated via I $\mathrm{KB}$ protein resynthesis and NF-kB reinhibition $[28,31,32]$.

From the multiple domains of NS1 of influenza $\mathrm{A}$ virus (NS1A) only one, the $\mathrm{N}$ terminal binding double stranded RNA domain, has been shown to be shared with the NS1 protein of influenza B virus(NS1B) [33].

Considering that the manipulation of apoptosis induction during influenza virus infection is partly associated with a motif of NS1A protein, with no homologous function in NS1B protein, we proposed to the apoptotic pathways that could be 
differently affected by influenza A (Both strains) and $B$ viruses.

\section{Materials and Methods \\ 2.1 Cells}

The IFN competent human cells include alveolar epithelial cell line A549 and were obtained from central public health laboratories in Egypt(CPHL), Madin Darby canine kidney cells (MDCK II), European Collection of Cell Cultures (ECACC), London, UK), recommended by World Health Organization for influenza virus replication and were obtained from central public health laboratories in $\operatorname{Egypt}(\mathrm{CPHL})$, were kept in maintenance medium containing Dulbecco's Modified Eagle Medium, (DMEM; Gibco, Paisley, UK), 2 mM 1-Glutamine (Gibco), 1× NEAA (NonEssential Amino acids, Gibco), and $24 \mathrm{mM}$ HEPES(N-2-hydroxyethylpiperazine-N-2-ethane sulfonic acid, Gibco) at $30^{\circ} \mathrm{C}$. MDCK II cells were subcultured at 3-4 $\times 10^{4}$ cells $/ \mathrm{cm} 2$ with growth medium (maintenance medium supplemented with10\% fetal bovine serum (FBS; Gibco). Growth medium was supplemented with $1 \mathrm{mg} / \mathrm{ml}$ Geneticin ${ }^{\circledR}($ Gibco) for cell line continuation or with $2.5 \mu \mathrm{g} / \mathrm{ml}$ Fungizone ${ }^{(}($Gibco) and $1 \times$ PSN (Penicillin-Streptomycin-Neomycin Antibiotic Mixture, Gibco) when cells were plated to be infected. Cultures were incubated at $37^{\circ} \mathrm{C}$ for $48 \mathrm{~h}$ prior to infection to reach a minimum of $90 \%$ mono-layer confluence.

\subsection{Viruses}

Influenza A (subtype A (H1N1) pdm09) (isolated in CPHL in Egypt) and influenza $\mathrm{A}$ (subtype A (H3N2) isolated in CPHL in Egypt) and influenza B/Yamgata (type B) isolated in CPHL in Egypt) viruses were propagated on MDCKII cells for stock constitution. Briefly, MDCK II cells in monolayer were infected with the virus; left to stand for $30 \mathrm{~min}$ for virus adsorption was as controls.

Monolayer of the cells at a concentration of $1 \times 10^{6}$ cells $/ \mathrm{mL}$ were infected with the virus at a multiplicity of infection (MOI) of 0.1 and 1.0 $\mathrm{PFU} /$ cell in the presence of supplemental trypsin. Following adsorption for $1 \mathrm{~h}$ at $37^{\circ} \mathrm{C}$, the inoculum was removed and washed before DMEM replaced.

The cultures were incubated up to 48 hours post infection (hpi) and observed by inverted light microscopy for cytopathic effect (CPE). For each cell, four different sets of tissue culture flask were infected. Mock Infected cells served were titrated before and after infection as described previously [34].

\subsection{Cell Viability Assay.}

A549 and MDCK cells were infected by H3N2, H1N1 PDM 09 and Influenza B virus at MOI of 0.1 and 1.0 PFU/cell and culture supernatants obtained at $8 \mathrm{~h}$ intervals up to $48 \mathrm{hpi}$. Cell viability following viral infection was determined by $3-(4$, 5-dimethylthiazol-2-yl)-2, 5-diphenyl tetrazolium bromide (MTT) assay.

In this case, each cell seeded in 96-well culture plates (approximately 5,000 cells per well) incubated with the related culture supernatants The cells were washed with PBS and incubated with DMEM and $50 \mu \mathrm{L} /$ well of MTT solution $(5 \mathrm{mg} / \mathrm{mL})$ for another $3 \mathrm{~h}$ at $37{ }^{\circ} \mathrm{C}$. Then, the medium was totally removed, and $200 \mu \mathrm{L}$ of $0.04 \mathrm{~N} \mathrm{HCl}$ in isopropanol was added to each well, and the plate was incubated for $1 \mathrm{~h}$ at room temperature. Optical density value was measured at $540 \mathrm{~nm}$ using an ELISA reader.

Cell survival was expressed as the ratio of virus infected to uninfected control. The three independent experiments were performed.

\subsection{LDH assay}

The media of infected cells were removed from each condition at $8,24,36$ and $48 \mathrm{~h}$ post infection (hpi) and centrifuged at $250 \times \mathrm{g}$ for $4 \mathrm{~min}$. Total cell death was determined by measuring the release of LDH from cells with the CytoTox96®Non-Radioactive Cytotoxicity Assay kit (Promega, Madison, IL, USA), according to the manufacturer's instructions. The cell monolayer was recovered for morphological analyses of apoptosis.

\subsection{DNA Fragmentation.}

Cell death was evaluated by fragmentation of genomic DNA. Samples of virus infected cells were centrifuged, and the cell pellet re-suspended in $300 \mathrm{~mL}$ of cold cell lysis buffer (10mMTris, $0.5 \%$ Triton $\mathrm{X}-100(\mathrm{pH} 7.5)$ ) then incubated on ice for $30 \mathrm{~min}$. The lysates were centrifuged at 12,000 $\mathrm{rpm}$ for $10 \mathrm{~min}$ at $4{ }^{\circ} \mathrm{C}$, and the supernatants were extracted once with buffered phenol and once with chloroform.

The DNA was precipitated with $300 \mathrm{mM} \mathrm{NaCl}$ and ethanol. DNA samples were resuspended in 50 $\mu \mathrm{L}$ of Tris-EDTA buffer $(10 \mathrm{mM}$ Tris, $1 \mathrm{mM}$ EDTA (pH 7.5)) treated with RNase A. The extracted DNAs were electrophoresed through a $2 \%$ agarose gel and stained with ethidium bromide.

\subsection{Fluorescent Microscopy.}

The mock and infected cells were washed twice with PBS and fixed with $4 \%$ paraformaldehyde before being stained with anti-mouse IgG: FITC conjugate to each $(1 \mathrm{mg} / \mathrm{mL})$ for $30 \mathrm{~min}$ at $37{ }^{\circ} \mathrm{C}$. 
Stained cells were observed with a fluorescence microscope (Olympus BX51).

\subsection{Real Time PCR Analysis}

Total RNA was extracted from cells using (Qiagen) according to the manufacturer's protocol. Five hundred nanograms of purified mRNA were used to generate cDNA with random hexamer primers (Thermo Scientific) and Revert Aid $\mathrm{H}$ Minus M-MuL V Reverse Transcriptase (Thermo Scientific) according to the manufacturer's protocol.

The quantitative real-time PCR (qRT-PCR) reaction mixture $(25 \mu \mathrm{l})$ consisted of the following: $12.5 \mu \mathrm{l}$ of Maxima SYBR green PCR master mix (Thermo Scientific), $0.5 \mu \mathrm{l}$ of cDNA template, and $1 \mu \mathrm{l}$ of each primer $(100 \mu \mathrm{M}$ forward and reverse primers) (Table 1). Reactions were run in duplicate on Applied Biosystems 7500 real-time PCR system. The cycling conditions were as follows: $2 \mathrm{~min}$ at $50^{\circ} \mathrm{C}, 2 \mathrm{~min}$ at $95^{\circ} \mathrm{C}$, and 50 cycles, with 1 cycle consisting of $15 \mathrm{~s}$ at $95^{\circ} \mathrm{C}$ and $30 \mathrm{~s}$ at $60^{\circ} \mathrm{C}$. Threshold cycle (CT) values were normalized to the values for the GAPDH control and compared $\beta$-actin controls Primers for realtime PCR of RNA transcripts.

\section{Results:}

To study the cytopathogenicity effect of the studied cells to Flu A/Pdm H1N1 09, Flu A/H3N2 and Flu B/Yamagata viruses, A549 and MDCK II cells were infected at MOI 0.1 and 1.0, although the marked CPEs were evident at 16 hpi for A549 cells infected with Flu B and H1N1 at higher MOI 1.0 which increased with time. At 24 hpi approximately half of the infected cells appeared smaller and irregularly shaped compared to mock cells. All studied influenza virus strains did not affect the CPE at MOI 0.1 on A549 cells (Figure 1). Infection of MDCK II cells with Flu B and $\mathrm{H} 1 \mathrm{~N} 1$ viruses caused a fast CPE especially at MOI 1.0 and a rapid fall in $\mathrm{pH}$ of cell suspension.

The granular and fragmented cells became obvious within 24 to 48 hpi. The infectious viruses were titrated by plaque assay at 16, 24 and $48 \mathrm{hpi}$. Higher viral titers were observed in infected A549 cells, and the peak of titer reached at $48 \mathrm{hpi}$; however, statistical differences were not observed between MDCK II and A549 cells at MOI 1.0. The mean peak titers of the INF B virus in these cells reached 4.3 and $4.4 \mathrm{PFU} / \mathrm{mL}$, respectively. The mean peak titers of the $\mathrm{H} 3 \mathrm{~N} 2$ virus in these cells reached 2.0 and 2.1 PFU/mL, respectively Until 48 hpi at both MOIs.
In addition, development of countable plaques required more days of incubation for $\mathrm{H} 3 \mathrm{~N} 2$ than other viruses.

The detection of lactate dehydrogenase (LDH) can be used to evaluate efficiently anti-influenza viruses' agents. LDH levels in the virus infected MDCK II and A549 cells were significantly higher than in controls, were in proportion to the degree of virus infection, and corresponded to a decrease in mitochondrial dehydrogenase activity.

LDH cytotoxicity assays were performed with different MOI of H3N2, Flu B and H1N1 viruses at $8 \mathrm{~h}$ interval exposure times in A549 and MDCK II cells (Fig 4a, 4b).

Induction of general cell death in Flu $\mathrm{A} / \mathrm{Pdm}$ H1N1 09, Flu A/H3N2 and Flu B/Yamagata infection differ in time and intensity. While cell death induced by INF $B$ occurred earlier in infection, at $24 \mathrm{~h}$ post-infection (hpi) ( $\mathrm{p}<0.05$ ), compared to $\mathrm{H} 1 \mathrm{~N} 1$ and $\mathrm{H} 3 \mathrm{~N} 2$ infection mediated cell death that occurs after 32 hpi (Fig. 4a, 4b) in both cell lines. The infected A549 and MDCK II cells at higher MOI showed significantly cell death confirming the DNA fragmentation and nuclear condensation results. Regarding intensity of cell death induced by infection, H1N1 was shown to be more virulent, reaching a maximum of 4 fold increased cell death at 48 hpi in MDCK II cells and up to 5 folds in A549 cells, compared with mock infection $(\mathrm{p}<0.01)$; exposure to INF B virus was shown to be less toxic to cells, the cell viability was decreased with the increase in virus MOI in A549 and MDCK II cells, Compared with mock and infected cells at MOI 1.0, Thus, these results suggest that LDH release and apoptosis start earlier, but with lower intensity, in cells infected with INF B than with H1N1 and H3N2 respectively (Fig 4a, 4b). A detectable DNA laddering in the virus infected cells appeared by 16 hpi at MOI 1.0 (Figure 3(b)). This Pattern significantly progressed at $48 \mathrm{hpi}$.

The INF B infected A549 cells demonstrated nuclear condensation, which can be detected by FITC staining, as show in Figure 3(a).,

The infected A549 cells undergoing apoptosis exhibited some cells with fragmented nuclei. The virus mainly caused cell death in MDCK II cells; therefore, it seems that H3N2, INF B and H1N1virus induced apoptosis in A549 cells in dose and time dependent manner (Fig 1,2a).

To determine whether the death receptor or mitochondrial pathways modulated apoptosis, samples from the infected cells were analyzed for the levels of expressions of pro-apoptotic marker 
bad and caspase 3, caspase 8 and caspase 9 using quantitative RT-PCR(Table 1).

The presence of a significance increase in the tested markers compared to mock and nonapoptotic cells indicating low level or undetectable tested markers in these cells (Table 2, 3 and 4).

A dose and time dependent activation of caspase 3 , caspase 8 and caspase 9 proteins was observed in H3N2, INF B and H1N1 infected A549 and MDCK II cells (Table 2, 3 and 4).

The levels of Caspase 8 protein activation was not detected in INF B infected MDCK II cells (Table 3); however the cell viability was significantly lower in MDCK II than A549infected cells (Figure 2).

The apoptotic markers in A549 and MDCK II cells were evaluated by quantitative RT-PCR (Table 1).

However, different regulation levels of MxA mRNA were observed in A549 and MDCK II cells infected by H1N1, H3N2 and INF B, expression of MxA gene was up regulated at 16 hpi which reached to maximal level at 24 hpi compared with mock cells; however, the higher dose of virus, a weaker MxA expression was detected (Table 2, 3 and 4). MxA expression showed similar pattern of induction peaking on 24 hpi and decreasing by 48hpi in MDCK II cells at both infectious doses in all studied influenza subtypes (Table 2, 3 and 4).

MxA mRNA expression for A549 cells was very high in response to INF $B$ infection Than H1N1 and H3N2 Infections. However it seems that the same order in MDCK II infected cell but with lower response than A549 infected cell (Table 2, 3 and 4)

\section{The delayed Onset of Cytopathogenicity by H3N2}

Influenza $\mathrm{H} 3 \mathrm{~N} 2$ virus infected A549 cells also elicited less TNF alpha and FasR transcription than either INF B or H1N1. These observations can account for the lower apoptotic response in influenza $\mathrm{H} 3 \mathrm{~N} 2$ virus infected lung (Fig 2b). As little impact on the expression of intrinsic pathway components was observed, it seems that the apoptotic response to influenza virus infection in A549 cells was mainly through the extrinsic pathways (Table 2).

The delayed onset of cytopathogenicity by H3N2 may take more than 96 hpi to obtain clear cytopathogenic effect compared to INFB or H1N1 Fig. (2b).

In addition, the pattern observed for general cell death seems to correlate with that observed for apoptosis, in all studied Influenza subtypes.
To evaluate potential differences of apoptotic signaling pathways triggered by influenza $A$ and $B$ viruses infections, the activity of several caspases was measured, such as the effector caspases 3 , the extrinsic pathway associated initiator caspase 8, and the intrinsic pathway associated initiator caspase 9.

Results showed that H1N1 and H3N2 infections induced caspase 3 activities from 16 to 48 hpi respectively(Table 2 and 4), In addition, the activity of effector caspases increased from $16 \mathrm{hpi}$ with INF B (Table 3), remaining higher than H1N1 and $\mathrm{H} 3 \mathrm{~N} 2$ respectively infected cells, and it was clear in A549 cells than MDCK II cells, until 48 hpi. In fact, this early effect of INFB in inducing the activity of effector caspases, when compared with $\mathrm{H} 1 \mathrm{~N} 1$ and $\mathrm{H} 3 \mathrm{~N} 2$ respectively, corroborates the previously observed apoptotic patterns (Table 2, 3 and 4).

The differences between $\mathrm{H} 1 \mathrm{~N} 1$ and $\mathrm{H} 3 \mathrm{~N} 2$ respectively and INF $\mathrm{B}$ virus mediated caspase activation were also evident for caspase 9 and caspase 8 (Table 2, 3 and 4).

The activity of caspase 9 slightly increased in $\mathrm{H} 1 \mathrm{~N} 1$ and $\mathrm{H} 3 \mathrm{~N} 2$ infected cells respectively during the first $48 \mathrm{hpi}$, when compared with mock infection (Table 2 and 4). In contrast, INF B induced lower levels of caspase 9 activity during the first $24 \mathrm{hpi}$ although persisting until $48 \mathrm{hpi}$, in MDCK II cell lines and undetectable in A549 cells (Table 3). Regarding caspase 8, the current study proved that activation of this death receptor related caspase was detected as early as $16 \mathrm{hpi}$ after INF B infection in A549 cells, where it can be detected less efficiency on MDCK II cells, becoming only evident at later stages of $\mathrm{H} 1 \mathrm{~N} 1$ and $\mathrm{H} 3 \mathrm{~N} 2$ infections respectively (Table 2, 3 and 4). Therefore, these results indicate that influenza H1N1, H3N2 and INF B viruses' infection mediate different apoptosis profiles.

INF B induces an immediate apoptotic response, but induced cell death levels are depending on the type of cells than those induced by $\mathrm{H} 1 \mathrm{~N} 1$ and H3N2 respectively (Table 2, 3 and 4). In addition, although all virus strains induced extrinsic and intrinsic apoptosis, $\mathrm{H} 1 \mathrm{~N} 1$ and $\mathrm{H} 3 \mathrm{~N} 2$ respectively prefer initially enhance the intrinsic pathway, as determined by caspase 9 activities and INF B prefer intrinsic pathway according to caspase 8 activity in A549 cell line but also can choose extrinsic pathway as determined by caspase 9 activity in MDCK II cells.

Influenza $A$ and $B$ viruses differentially regulate $\mathrm{NF}-\mathrm{kB}$ activation. 
One of the important signaling factors for virus replication is the transcription factor NF-kB, also commonly regarded as a major regulator of the innate immune defense to infection. In fact, NF$\mathrm{kB}$ is often activated by viruses; leading to the up regulation of a variety of antiviral genes. Several molecular mechanisms have been identified to confer this virus-supportive function of NF-kB. First, it was shown that NF-kB acts via induction of pro-apoptotic factors, such as TNF related apoptosis inducing ligand (TRAIL) or FasL, and subsequent activation of caspases [35].

To address whether differences in apoptosis profiles between Influenza A and B strains depend on NF- $\mathrm{kB}$ factor, the levels of NF- $\mathrm{kB}$ versus its endogenous inhibitor, The I $\kappa \mathrm{B}$ (inhibitor of kappa $\mathrm{B})$ and Tumor necrosis factor alpha (TNF $\alpha)$ which induced NF-kB activation [36] were evaluated throughout $\mathrm{H} 1 \mathrm{~N} 1, \mathrm{H} 3 \mathrm{~N} 2$ and INF $\mathrm{B}$ virus infection respectively and compared between all strains (Table 2 - 4). The analysis of the TNF $\alpha$ and $\mathrm{I} \kappa \mathrm{B}$ protein levels revealed that infection with INF $\mathrm{B}$ induced TNF $\alpha$ and I $\mathrm{B} B$ ratio earlier at $16 \mathrm{hpi}$, higher than that observed in mock infection in both cell lines (Table 2, 3 and 4).

Regarding H1N1 and H3N2 infections respectively, although the maximum value for $\mathrm{TNF} \alpha$ and IKB ratio was also observed at 16 and $48 \mathrm{hpi}$, it remained always higher than that detected for $\mathrm{H} 1 \mathrm{~N} 1$ and $\mathrm{H} 3 \mathrm{~N} 2$ respectively, at 16 and $48 \mathrm{hpi}$, or for mock infection, during 16 and 48 hpi. This may be explained by the continuous increase of IKB $\alpha$ protein levels throughout INF B infection (Table 2, 3 and 4). To confirm whether influenza $A$ or $B$ strains mediated increase in $\mathrm{TNF} \alpha / \mathrm{I} \kappa \mathrm{B}$ ratio reflects the enhancement in NF$\mathrm{kB}$ activity, the transcriptional activity of NF- $\mathrm{kB}$ was studied throughout H1N1, H3N2, INF B and mock infections periods. From the upper data, these results revealed that NF- $\mathrm{kB}$ survival pathway activation might be the responsible factor for the distinct apoptosis profiles induced by H1N1, H3N2 and INF B infections. Curiously, in this cellular context, NF- $\mathrm{kB}$ might be activated by mechanisms dependent on the regulation of $\underline{\mathrm{IKB}}$ protein levels.

\section{DISCUSSION}

Viruses have evolved multiple and complex strategies to subvert and evade the host immuneresponse to ensure their own replication and survival [31, 37, 38].

Although the death receptor-mediated apoptosis pathway induced by influenza infection has been extensively studied [39, 40, 41], little is known about the differences in the kinetics and pathways of apoptosis induction in influenza A and B virus infections. Early in infection, viral NS1 binds to the PI3K subunit p85 and activates the kinase [23]

This results in activation of Akt/PKB via phosphorylation (by pyruvate dehydrogenase kinase and the mammalian target of rapamycin complex 2 [42].

Activated Akt negatively regulates pro-apoptotic factors [caspase 3, caspase 9, Bcl-2 associated death promoter (BAD), GSK-3] and thereby suppresses early apoptosis [43].

At later stages of infection, the virus-induced NF-kB activation leads to the expression of proapoptotic factors (Fas, FasL, TRAIL) and thereby, to caspase induction, resulting in increased RNP export [28].

During productive virus infection, the proapoptotic factors TRAIL and FasL are expressed in an NF-kB-dependent manner.

The classical mechanism of NF-kB activation includes activation of IKK, which phosphorylates the inhibitor of NF-kB and IkB and targets the protein for subsequent degradation. This leads to the release and migration of the transcriptionally active NF-kB factors, such as $\mathrm{p} 65$ or $\mathrm{p} 50$, to the nucleus [42].

The early induction of extrinsic pathway of apoptosis by INF B infection, detected by the increase in the activity of the initiator caspase 8, reveals the inability of INF B strain to avoid cell death through this pathway.

Curiously, the extrinsic pathway of apoptosis has been previously associated to the innate antiviral cell response that leads to the production of interferon (IFN) $\alpha$, IFN $\beta$ and cytokines capable of inducing apoptosis by the TNF-related apoptosis ligand (TRAIL) pathway, which in turn trigger the extrinsic pathway of apoptosis by the cell death receptor pathway $[17,44]$.

In contrast, the induction of the extrinsic apoptosis pathway was only observed for influenza A infection at $16 \mathrm{hpi}$, reflecting the ability of the influenza A virus to counteract with this antiviral cell response.

The PI3K/Akt pathway, one of the pathways hijacked by the NS1protein of influenza A virus, was already shown to be responsible for a delay in induction of apoptosis in the host cells [45]

The PI3K/Akt pathway was activated in a similar extent by the influenza A and B strain infection. However, Influenza A strain was able to induce a second activation of this pathway later throughout the infection period (24 hpi). 
Although the initial activation of this pathway by influenza $A$ strain could partially explain the delay in apoptosis induction of influenza $\mathrm{A}$ in comparison with INF $\mathrm{B}$, additional mechanisms must be in place by influenza $\mathrm{A}$ in infected cells to block pre-activated apoptosis and avoid cell loss $[3,5]$.

We have provided experimental evidence that influenza viruses, including trigger an apoptotic response mediated by caspases activation that is similar to, but delayed compared with that induced by human influenza viruses including $\mathrm{H} 1 \mathrm{~N} 1$ and INF B.

Activated caspase 8 is able to cleave additional downstream caspases and also activate Bid, aproapoptotic member of the $\mathrm{Bcl}-2$ proteins resulted in an efflux of cytochrome c into the cytoplasm [46].

The viral infection at higher MOI induced cleavage of pro-caspase 8 into intermediate p4143 at the earlier stage of infection (24 hpi) followed by activation to its p18 active at $48 \mathrm{hpi}$ using an antibody directed against the $\mathrm{N}$ terminal fragment of this protein [34].

Although NF- kB activation has already been associated with the antiviral response of the influenza A infected cells [44, 47].

It is possible that NF- $\mathrm{kB}$ may also be required for Influenza A virus replication by activating the transcription of anti-apoptotic factors [4, 48].

In fact, when comparing with influenza B strain, influenza A strain infection markedly increased the levels of the NF- $\mathrm{kB}$ downstream survival targets, including Bcl-XL and XIAP. However, the influenza A mediated effects were only associated with a delay in apoptosis induction, rather than within crease in apoptotic resistant of infected cells.

Although the differences observed in kinetics and pathways of induction of apoptosis between influenza $\mathrm{A}$ and $\mathrm{B}$ strain infections point to occur at the IkB/NF- $\mathrm{kB}$ level, further studies are required to clarify the molecular mechanisms by which influenza B virus induce IkB accumulation.

A better understanding of the molecular mechanisms by which influenza $A$ and $B$ viruses regulate apoptosis in host cells has also the potential to uncover the networks of factors that may contribute for a successfully influenza virus replication, crucial for the development of vaccines and antiviral drugs $[5,28]$.

Influenza $A$ and $B$ viruses differentially modulate the expression of IKB protein level

To analyze the differences on apoptosis regulatory mechanisms between $\mathrm{H} 1 \mathrm{~N} 1$ and $\mathrm{H} 3 \mathrm{~N} 2$ and INFB infection, namely the involvement of
IKB protein level activation in these events, the expression levels of survival downstream targets of IKB protein level, including pro-apoptotic BAD levels were studied throughout the infection periods.

RT PCR showed that although BAD levels highly pronounced in INFB than in $\mathrm{H} 1 \mathrm{~N} 1$ and $\mathrm{H} 3 \mathrm{~N} 2$ respectively. In fact, at $16 \mathrm{hpi}$, INFB showed higher levels of $\mathrm{BAD}$ when compared with mock infection. The levels of BAD were expressed in lower levels when compared with those observed after $16 \mathrm{~h}$ of $\mathrm{H} 1 \mathrm{~N} 1$ and $\mathrm{H} 3 \mathrm{~N} 2$ infection. These findings suggests distinct regulatory networks of apoptosis between H1N1 and $\mathrm{H} 3 \mathrm{~N} 2$ and INFB infection, which might support the role of the pro-survival factor NF- kB and its targets genes in delaying apoptosis initiation upon and $\mathrm{CPE}$ in $\mathrm{H} 3 \mathrm{~N} 2$ infection compared with influenza B and H1N1 infection respectively.

Influenza virus-induced cytopathic effect (CPE) and cell death are inhibited in BAD deficient cells. Influenza virus killing of host cells is known to occur through the activation of the apoptotic signaling pathway [49].

$\mathrm{BAD}$ is an important regulator of antiapoptotic $\mathrm{Bcl}-2$ and $\mathrm{Bcl}-\mathrm{xL}$ proteins. Its blockage of $\mathrm{Bcl}-2$ and Bcl-xL defines the fate of the host cell toward apoptosis.

Infected cells were examined visually for demonstration of cytopathic effect (CPE), which phenotypically manifests as rounding up and detachment of infected cells as well as abnormal cellular structural morphology BAD knockdown in A549 cells reduced influenza virus replication of different virus subtypes.

A number of studies have reported the importance apoptosis plays in promoting efficient influenza virus replication $[38,50]$.

The delayed onset of apoptosis by $\mathrm{H} 3 \mathrm{~N} 2$ influenza virus infected respiratory epithelial cells A549 may be a mechanism for the influenza viruses to have more prolonged replication within the human respiratory tract, and this may contribute to the pathogenesis of human disease[51].

In contrast to [50] the delayed $\mathrm{CPE}$ in the H1N2 infected cells might result from decrease of cell death rate, cytochrome $c$ release and apoptosome formation as compared to those of $\mathrm{H} 1 \mathrm{~N} 1$ and $\mathrm{H} 3 \mathrm{~N} 2$ infected cells.

Our study also showed that the considerable MxA expression was found in influenza A and B virus, infected A549 and MDCK II cells at low dose of the virus. 
MxA mRNAs were induced in the infected A549 cells in a dose dependent manner, correlating with the replication of influenza $A$ and $B$ virus in the cell. Activation of the cellular antiviral defense by MxA expression decreases virus replication at early time of infection which had not significant impact on final virus titers. The result suggests a role for IFN response in the replication of influenza $\mathrm{A}$ and $\mathrm{B}$ virus that may provide some degree of host resistance in the early stages of infection. In contrast to MDCK II, the A549 cells are IFN-competent cells, and MxA is up-regulated in these cells while the protein is either downregulated or even undetectable in MDCK II cell in response to influenza $\mathrm{A}$ and $\mathrm{B}$ infection. Thus, an insufficient antiviral defense in MDCK II cells promotes efficient influenza $\mathrm{A}$ and $\mathrm{B}$ virus replication which is controlled in part by the IFN response. Taken together, the results demonstrated that the permissively of noncompeting IFN MDCK II cells for influenza A and B influenza virus is comparable with A549 cells; however, kidney cells are not target tissue respond to the infection. These data revealed that the sensitivity of human alveolar epithelial cells to influenza $\mathrm{A}$ and $\mathrm{B}$ induced apoptosis signaling via intrinsic and extrinsic pathways in parallel, and the induction was associated with viral infection in a dose dependent manner.

\section{Conclusion}

In conclusion Influenza viruses afflict millions of people each year and cause serious medical complications. Because of the high genetic variability of influenza viruses, the development of effective vaccines against pandemic influenza is still an ongoing challenge. In addition, although all virus strains induced extrinsic and intrinsic apoptosis, $\mathrm{H} 1 \mathrm{~N} 1$ and $\mathrm{H} 3 \mathrm{~N} 2$ respectively prefer initially enhances the intrinsic pathway, as determined by caspase 9 activity and INF B prefer intrinsic pathway according to caspase 8 activity in A549 cell line but also can choose extrinsic pathway as determined by caspase 9 activity MDCK II cells.

\section{Acknowledgements}

The authors would like to thank DR Amany El Gohary, $\mathrm{PhD}$, Head of the virology Departments center public Health Labs (CPHL) for her efforts, Dr. Amer Sayed Ahmed and Dr. Shimaa Ibrahim in molecular biology and virus isolation units in CPHL for their great efforts and for viruses and cell lines supports .

\section{References}

1- Steven F. Baker, Aitor Nogales, Courtney Finch,d Kevin M. Tuffy, William Domm, Daniel R. Perez,d David J. Topham, Luis Martínez Sobridoa, 2014 .Influenza A and B Virus Intertypic Re-assortment through Compatible Viral Packaging Signals. J. Virol., 79: 10778-10791.

2- Sweet, C. and Smith, H., 1980, Pathogenicity of influenza virus. Microbiol. Rev., 44:303-330.

3- Graeme E. Price, Harry Smith and Clive Sweet, 1997.Differential induction of cytotoxicity and apoptosis by influenza virus strains of differing virulence. J. Gen. Virol., 78:2821-2829.

4-Ludwig, S., Planz, O., 2008.Influenza viruses and the NF-kappa B signaling path-way towards a novel concept of antiviral therapy. Biol. Chem., 389(10):1307-1312.

5-Luis A Santosa, Susana Solác, Cecilia MP Rodriguesc, Helena Rebelo de Andradea, 2015. Distinct kinetics and pathways of apoptosis in influenza A and B virus infection. Virus Res. J., 205:33-40.

6- Rebelo de Andrade, H., Diniz, A., Froes, F., 2003. Gripe, Sociedade Portuguesa de Pneumologia, Lisboa

7- Fields, B.N., Knipe, D.M., Howley, P.M., 2007.Fields Virology," 2. Fifth ed. Wolters Kluwer Health/Lippincott Williams \& Wilkins, Philadelphia; London.

8- Takizawa T, Matsukawa S, Higuchi Y, Nakamura S, Nakanishi Y, Fukuda R., 1993. Induction of programmed cell death (apoptosis) by influenza virus infection in tissue culture cells. J. Gen. Virol. 74: 2347-2355.

9-Gaur P., Munjhal A., La S.K., 2011. Influenza virus and cell signaling pathways. Med. Sci. Monit., 17(6): 148-154.

10-Konig, R., Stertz, S., Zhou, Y., Inoue, A., Hoffmann, H.H., Bhattacharyya, S., Alamares,J.G., Tscherne, D.M., Ortigoza, M.B., Liang, Y., Gao, Q., Andrews, S.E., Bandyopadhyay, S., De Jesus, P., Tu, B.P., Pache, L., Shih, C., Orth, A., Bonamy, G., Miraglia, L.,Ideker, T., Garcia-Sastre, A., Young, J.A., Palese, P., Shaw, M.L., Chanda, S.K., 2010.Human host factors required for influenza virus replication. Nature. 463(7282): 813-817,

11-Krug, R.M., Yuan, W., Noah, D.L., Latham, A.G., 2003.Intracellular warfare between human influenza viruses and human cells: the roles of the viral NS1 protein. Virology, 309(2): 181-189.

12- Hinshaw VS, Olsen CW, Dybdahl Sissoko NR, Evans D, 1994.Apoptosis: a mechanism of cell killing by influenza A and B viruses. J. Virol. 68:3667-3673. 
13- Ludwig S, Pleschka S, Planz O, Wolff T., 2006.Ringing the alarm bells: signaling and apoptosis in influenza virus infected cells. Cell. Microbiol. 8:375-386.

14- Kleinschmidt MC, Michaelis M, Ogbomo H, Doerr H-W, Cinatl J, Jr., 2007.Inhibition of apoptosis prevents West Nile virus induced cell death. BMC Microbiol. 7(49):1-8.

15-Qian Gaoa, Zhen Wanga, Zhen long Liua, Xiaoyu Lia, Yongxin Zhanga, Zhizhen Zhangb, Shan Cena, 2014.A cell based high throughput approach to identify inhibitors of influenza A virus. Acta Pharmaceutica Sinica B. 4(4):301-306. 16-Baskin CR, Garci Sastre A, Tumpey TM, Bielefeldt Ohmann H, Carter VS, Nistal Villan E, Katze MG. 2004. Integration of clinical data, pathology, and cDNA microarrays in influenza virus infected pigtailed macaques (Macaca nemestrina). J. Virol. 78:10420 -10432,

17- Cillóniz C, Shinya K, Peng X, Korth MJ, Proll SC, Aicher LD, Carter VS, Chang JH, Kobasa D, Feldmann F, Strong JE, Feldmann H, Kawaoka Y, Katze MG., 2009. Lethal influenza virus infection in macaques is associated with early dysregulation of inflammatory related Genes. PLoS Pathog. 5(10): 1-12.

18-Shahla Shahsavandi, Mohammad Majid Ebrahimi, Kaveh Sadeghi, Seyedeh Zahra Mosavi, and Ashraf Mohammadi, 2013.Dose- and TimeDependent Apoptosis Induced by Avian H9N2 Influenza Virus in Human Cells. BioMed Res. Int. 2013: 1-7.

19-Duprez L, Wirawan E, Berghe TV, Vandenabeele P., 2009. Major cell death pathways at a glance. Microbes Infect., 11:1050 -1062.

20- Levine B, Sinha S, Kroemer G., 2008.Bcl-2 family members. Autophagy, 4: 600-606.

21- Autret A, Martin SJ. 2009. Emerging role for members of the Bcl-2 family of mitochondrial morphogenesis .Mol. Cell, 36:355-363.

22-Chen, C., Edelstein, L.C., Gelinas, "The Rel/NF-kappa B family directly activates expression of the apoptosis inhibitor Bcl-x (L), 2000.Mol. Cell. Biol., 20 (8):2687-2695.

23-Kroesen, B.J., Teteloshvili, N., Smigielska Czepiel, K., Brouwer, E., Boots, A. M., van den Berg, A., Kluiver J.2015. Immuno-miRs: critical regulators of $\mathrm{T}$ cell development, function and ageing. Immunology, 144(1):1-10.

24- Clive Sweet, Susan J. Morrisa, Mustafa A. Mohsina, Harry Smith, 2001. Mechanisms of differential induction of apoptosis by $\mathrm{H} 3 \mathrm{~N} 2$ and $\mathrm{H} 1 \mathrm{~N} 1$ influenza viruses. International Congress Series, 1219: $573-579$.
25- Yang E, Zha J, Jockel J, Boise LH, Thompson CB, Korsmeyer SJ., 1995.Bad, a heterodimeric partner for Bcl-xL and Bcl-2.Cell, 80:285-291.

26- Zha J, Harada H, Osipov K, Jockel J, Waksman G, Korsmeyer SJ., 1997.BH3 domain of $\mathrm{BAD}$ is required for hetero dimerization with BCL-XL and pro-apoptotic activity. J. Biol. Chem., 272:24101-24104.

27-Baldwin Jr., A.S., 1996.The NF-kappa B and I kappa B proteins" new discoveries and insights. Annu. Rev. Immunol. 14: 649-683,

28-James M. Hill, Christian Clement, Yuhai Zhao and Walter J. Lukiw, 2015.Induction of the proinflammatory NF-Kb sensitive miRNA 146a by human neurotrophic viruses. Front. Microbiol., 6(43):1-6.

29-Catz, S.D., Johnson, J.L., 2001.Transcriptional regulation of bcl 2 by nuclear factor kappa $\mathrm{B}$ and its significance in prostate cancer. Oncogene, 20(50): 7342-7351.

30-Ho,B.C.,Yu,I.S.,Lu,L.F.,Rudensky,A.,Chen,H. Y., Tsai C.W., et al., 2014.Inhibition of miR-146a prevents enterovirus induced death by restoring the production of type I interferon. Nat. Commun. 5(3344):.1-14.

31-Hill, J.M. Zhao, Y. Clement, C. Neumann D.M., and Lukiw W.J, 2009.HSV1infectionofhuman brain cells induces miRNA146a and Alzheimer type inflammatory signaling. Neuroreport. 20:1500-1505,

32 - Kim R., 2005.Unknotting the roles of Bcl-2 and Bcl-xL in cell death. Biochem. Biophys. Res. Commun, 333:336-343.

33 -Yuan W., Aramini, J.M. Montelione, G.T. Krug R.M., and 2002.Structural basis for ubiquitin like ISG 15 protein binding to the NS1 protein of influenza B virus: a protein protein interaction function that is not shared by the corresponding $\mathrm{N}$ terminal domain of the NS1 protein of influenza A virus. Virology, 304(2):291-301.

34-Shahla Shahsavandi, M. M. Ebrahimi, A. Mohammadi, and N. Z. Lebas, 2013.Impact of chicken-origin cells on adaptation of a low pathogenic influenza virus. Cytotechnology, 65: 419-424.

35-Stephan Ludwig, 2009.Targeting cell signaling pathways to fight the flu: towards a paradigm Change in anti-influenza therapy .J. Antimicrob. Chemotherapy, 64: 1-4.

36- Ken Blackwell a Laiqun Zhang, a Lauren M. Workman, b Adrian T. Ting, c Kazuhiro Iwai, d Hasem Habelhaha, 2013.Two Coordinated Mechanisms Underlie Tumor Necrosis Factor 
Alpha Induced Immediate and Delayed IB Kinase Activation. Mol. Cell Biol. J. 33(10):1901-1915.

37-Kodaman, N., Sobota, R. S., Mera,R., Schneider, B.G., and Williams ,S.M., 2014.Disrupted human pathogen co-evolution : a model for disease. Front. Genet. 5(290):1-12.

38-Xing Z, Harper R, Anunciacion J, Yang Z, Gao W, Qu B, Guan Y, Cardona CJ. 2011. Host immune and apoptotic responses to avian influenza virus H9N2 in human tracheobronchial epithelial cells. Am. J. Respir. Cell \& Mol. Biol. 44(1):2433.

39-Takizawa T, Tatematsu C, Ohashi K, Nakanishi Y., 1999. Recruitment of apoptotic cysteine proteases (caspases) in influenza virus induced cell death. Microbiol. Immunol. 43:245-250.

40-Wada N, Matsumura M, Ohba Y, Kobayashi N, Takizawa T, Nakanishi Y., 1995.Transcription stimulation of the Fas-encoding gene by nuclear factor for interleukin 6 expression upon influenza virus infection. J. Biol. Chem., 270:18007-18012,

41-Young Ki Choi, Tae Kyung Kim, Chul-Joong Kim, Joong-Seob Lee, Se Young Oh, Han Soo Joo, Douglas N. Foster, Ki Chang Hong, Seungkwon You and Hyunggee Kim, 2006.Activation of the intrinsic mitochondrial apoptotic pathway in swine influenza virus mediated cell death. Exp. Mol. Med., 38(1) 11-17.

42-Susanne Herold, Stephan Ludwig, Stephan Pleschka, and Thorsten Wolff, 2012.Apoptosis signaling in influenza virus propagation, innate host defense, and lung injury. J. Leuk. Biol., 92: 75-82.

43-Xinya Lu, Aleksandar Masic, Yang Li, Yeun Kyung Shin, Qiang Liu1 and Yan Zhou, 2010. The PI3K/Akt pathway inhibits influenza A virus induced Bax mediated apoptosis by negatively regulating the JNK pathway via ASK1. J. Gen. Virol., 91: 1439-1449.

44- Dirk Mulbauer,Julia Dzieciolowski, Martin Hardt, Kristina L.Schierhom, Ahmed Mostafa, Christiain Wisskirchen, Susanne Herold, Thorsten Wolff, John Ziebuhr and Stephan Pleschka., 2015. Influenza Virus Induced Caspase Dependent Enlargement of Nuclear Pores Promotes Nuclear Export Of Viral Ribonucleoprotein Complexes. J. Virol. 89(21):136.
45-Shin, Y.K., Li, Y., Liu, Q., Anderson, D.H., Babiuk, L.A., Zhou, Y., 2007.SH3 binding motif1 in influenza A virus NS1 protein is essential for PI3K/Akt signaling pathway activation. J. Virol. 81(23):12730-12739.

46-Brydon EWA, Morris SJ, Sweet C., 2005.Role of apoptosis and cytokines in influenza virus morbidity. FEMS Microbiol. Rev. 29:837-850.

47-Wang, C., Gao, L., Jin, Y., Cardona, C. J., and Xing, Z., 2014.Regulation of host responses and viral replication by the mitogen activated protein kinases in intestinal epithelial cells infected with Enterovirus71. Virus Res. 197C: 75-84.

48-Shapira, S.D., Gat-Viks, I., Shum, B.O., Dricot, A., de Grace, M.M., Wu, L., Gupta, P.B.,Hao, T., Silver, S.J., Root, D.E., Hill, D.E., Regev, A., Hacohen, N., 2009.A physical and regulatory map of host influenza interactions reveals pathways in H1N1infection. Cell, 139(7):1255-1267.

49-McLean JE, Datan E, Matassov D, Zakeri ZF. 2009. Lack of Bax prevents influenza A virusinduced apoptosis and causes diminished viral replication,” J. Virol., 83:8233-8246.

50- Uiprasertkul, M. Kitphati, R. Puthavathana, P. Kriwong,R. Kongchanagul,A. Ungchusak,K. Angkasekwinai,S. Chokephaibulkit, K. Srisook, K. Vanprapar, N. and Auewarakul, P. 2007.Apoptosis and pathogenesis of avian influenza $\mathrm{A}(\mathrm{H} 5 \mathrm{~N} 1)$ virus in humans. Emerg. Infect. Dis. 13(5): 708-712.

51-Kit M Yuen, Renee WY Chan, Chris KP Mok1, Adam CN Wong, Sara SR Kang, John M Nicholls, and Michael CW Chan, 2011.Differential onset of apoptosis in avian influenza $\mathrm{H} 5 \mathrm{~N} 1$ and seasonal H1N1 virus infected human bronchial and alveolar epithelial cells: an in vitro and ex vivo study," Influenza Other Respir. Viruses. 5(1): 437-438. 
Table 1:

\begin{tabular}{|l|l|l|}
\hline Name & DIRECTION & Sequence 5' $^{\prime} \rightarrow{ }^{\prime}$ \\
\hline MxAF & forward primer, & TTCAGCACCTGATGGCCTATC \\
\hline MxAR & reverse primer & TGGATGATCAAAGGGATGTGG \\
\hline b-actin & forward primer & GAG ACC TTC AAC ACC CCG C \\
\hline b-actin & reverse primer & ATG TCA CGC ACG ATT TCC C \\
\hline BAD & forward primer & ACCCGGCAGACAGATGAG \\
\hline BAD & reverse primer & CTTCCTCTCCCACCGTAGC \\
\hline I B & forward primer & CAGCAGACTCCACTCCACTT \\
\hline IאB & reverse primer & GAGAGGGGTATTTCCTCGAA \\
\hline TNF- $\alpha$ & forward primer & CTCTTCTCCTTCCTGATCGTGGCA \\
\hline TNF- $\alpha$ & reverse primer & GTTGGATGTTCGTCCTCCTCACA \\
\hline CASPASE 3 & forward primer & TTAATAAAGGTATCCATGGAGAACACT \\
\hline CASPASE 3 & reverse primer & TTAGTGATAAAAATAGAGTTCTTTTGTGAG \\
\hline CASPASE 9 & forward primer & AGCCAGATGCTGTCCCATAC \\
\hline CASPASE 9 & reverse primer & CAGGAGACAAAACCTGGGA \\
\hline CASPASE 8 & forward primer & CTGGGAAGGATCGACGATTA \\
\hline CASPASE 8 & reverse primer & CATGTCCTGCATTTTGATGG \\
\hline GAPDH & forward primer & GGCATTGCTCTCAATGACAA \\
\hline GAPDH & reverse primer & TGTGAGGGAGATGCTCAGTG \\
\hline
\end{tabular}

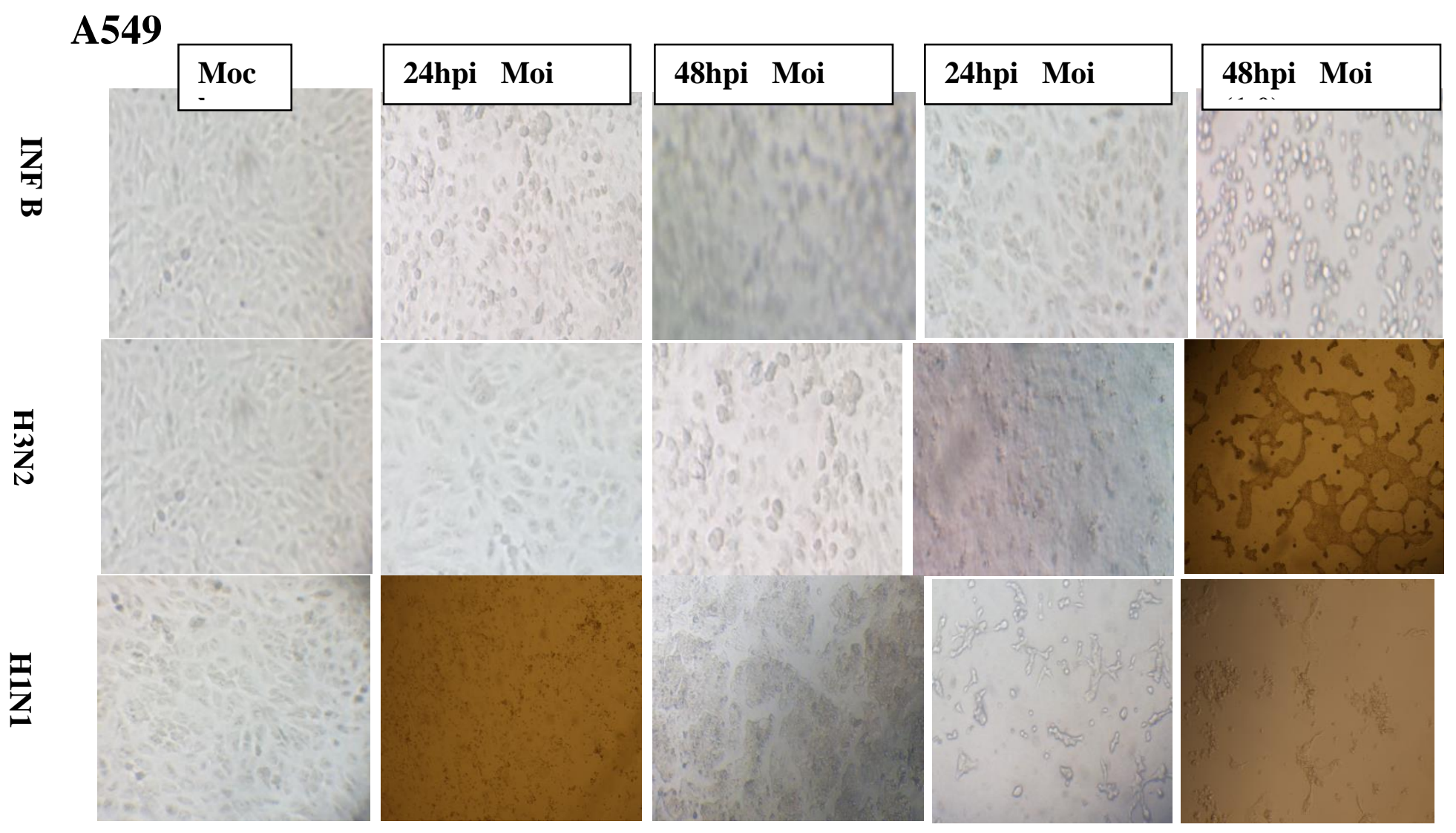

Figure 1: Cytopathogenicity of A549 cells to an Influenza A and b viruses infection at 24 and 48 hours after infection (10x magnification). 


\section{2(a) MDCK II}

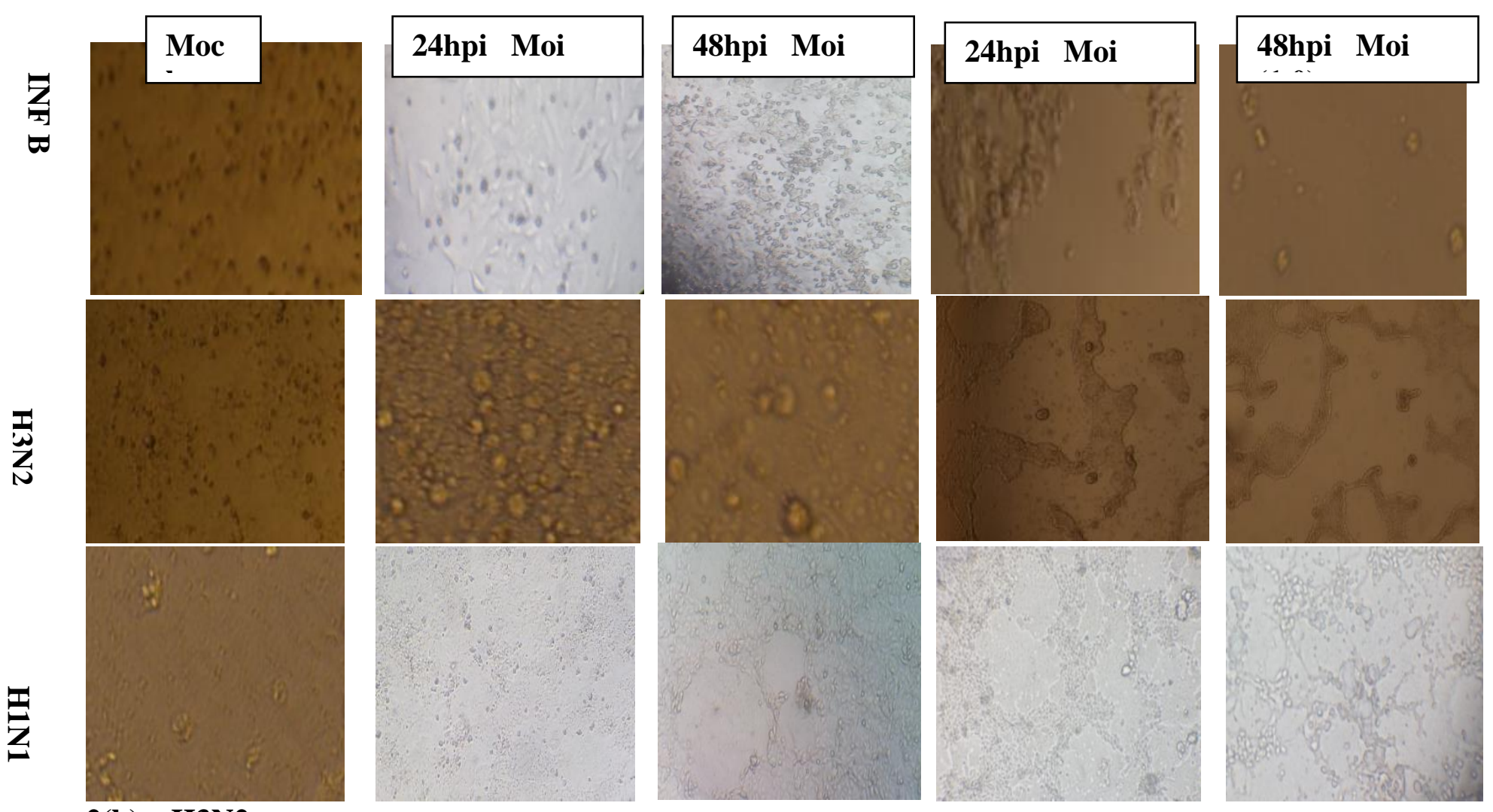

\section{2(b) H3N2}
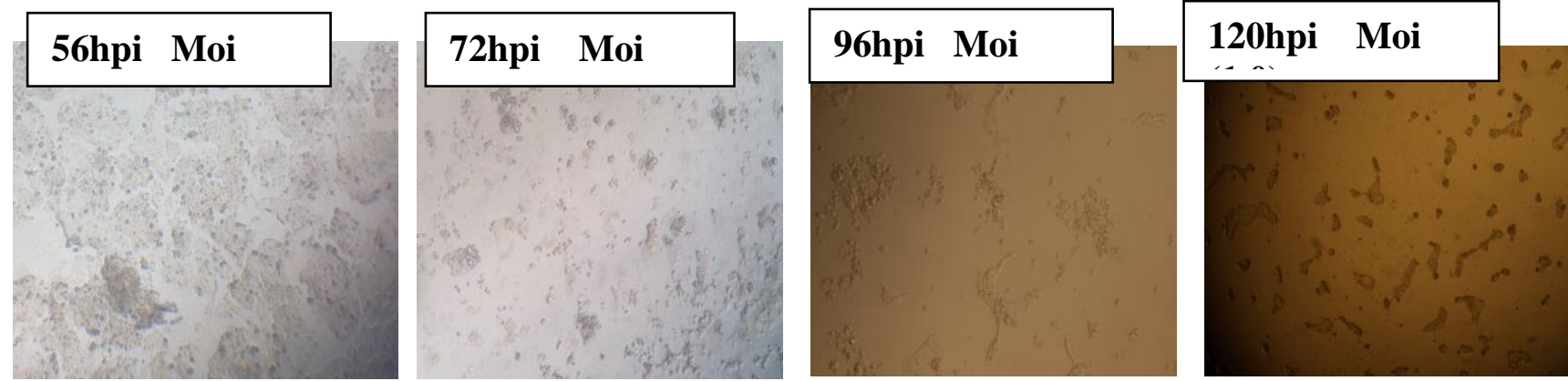

Figure 2: (a)Cytopathogenicity of MDCK II cells to an Influenza A and B viruses infection at 24 and 48 hours after infection,(b) The delayed Onset of cytopathogenicity by H3N2 (10x magnification). 


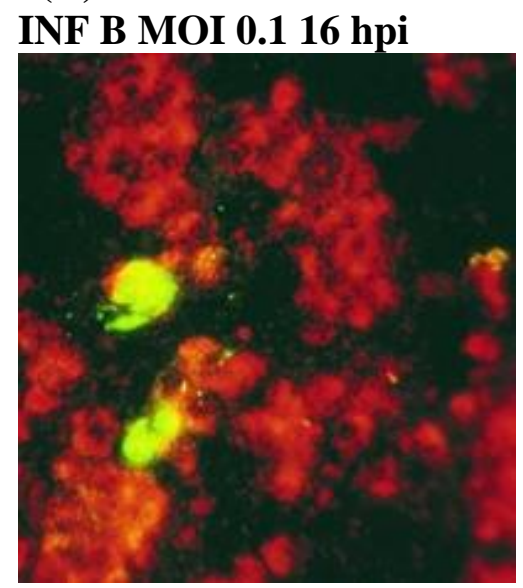

H3N2 MOI 1.016 hpi
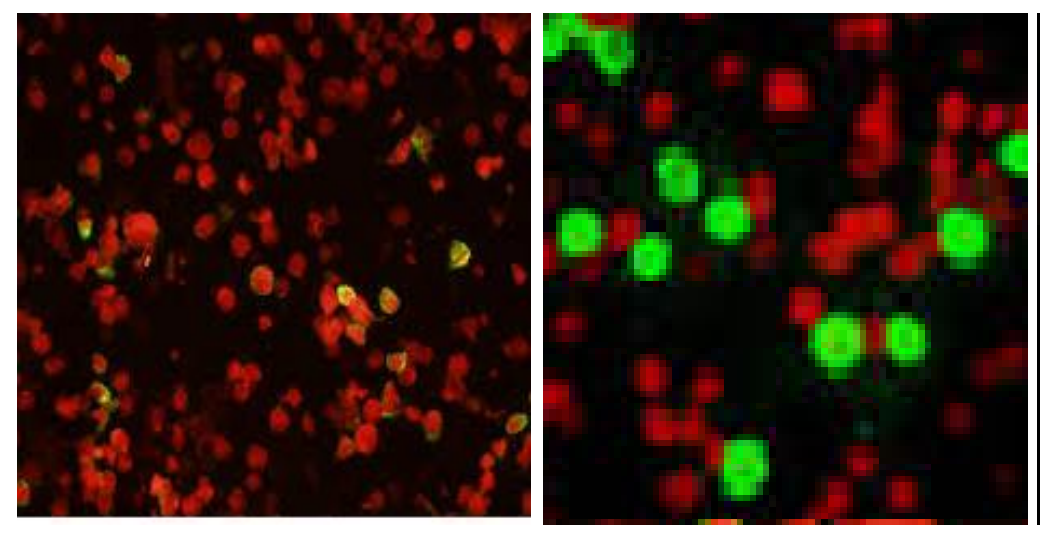

H1N1 MOI 0.116 hpi

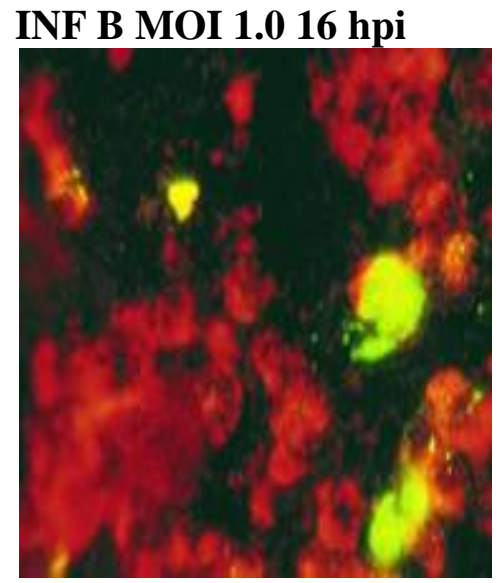

H3N2 MOI 0.1 16 hpi

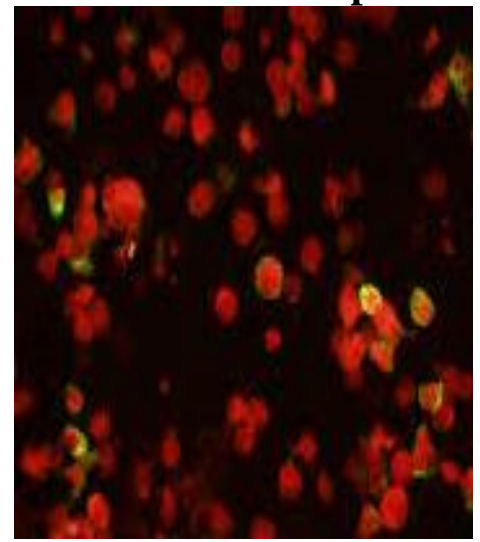

H1N1 MOI 0.116 hpi

3(B)

\section{INF B}

Mock 8hpi 16hpi 24hpi 36 hpi 48 hpi

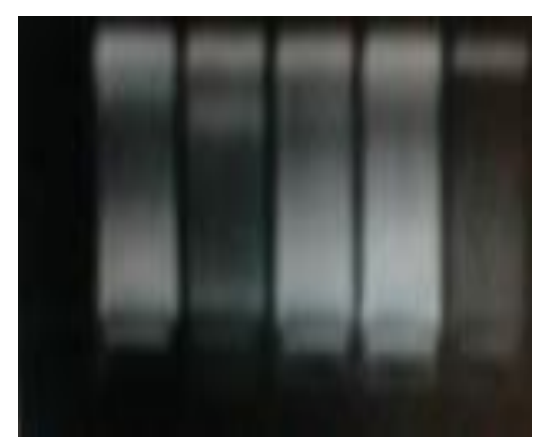

\section{INFLUENZA A}

Mock 8hpi 16hpi 24hpi 36 hpi 48 hpi

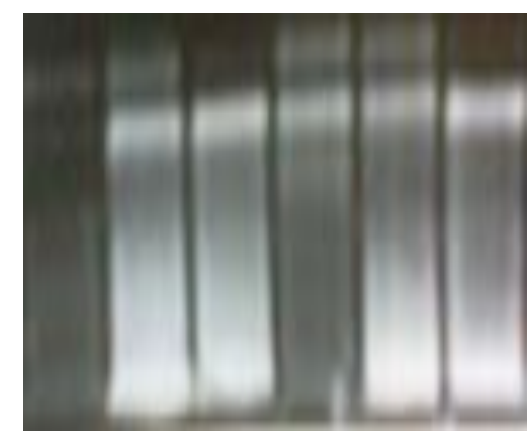

Figure 3: Influenza A and B viruses induces apoptosis in A549 and MDCK II cells at MOI 1.0. (a) Nuclear staining of the infected cells with FITC staining (b) Chromosomal DNA fragmentation. DNAs were prepared from A549 cells infected with virus at $8 \mathrm{~h}$ intervals and separated by $2 \%$ agarose gel electrophoresis, followed by staining with ethidium bromide. 


\section{4(a) MDCK II}
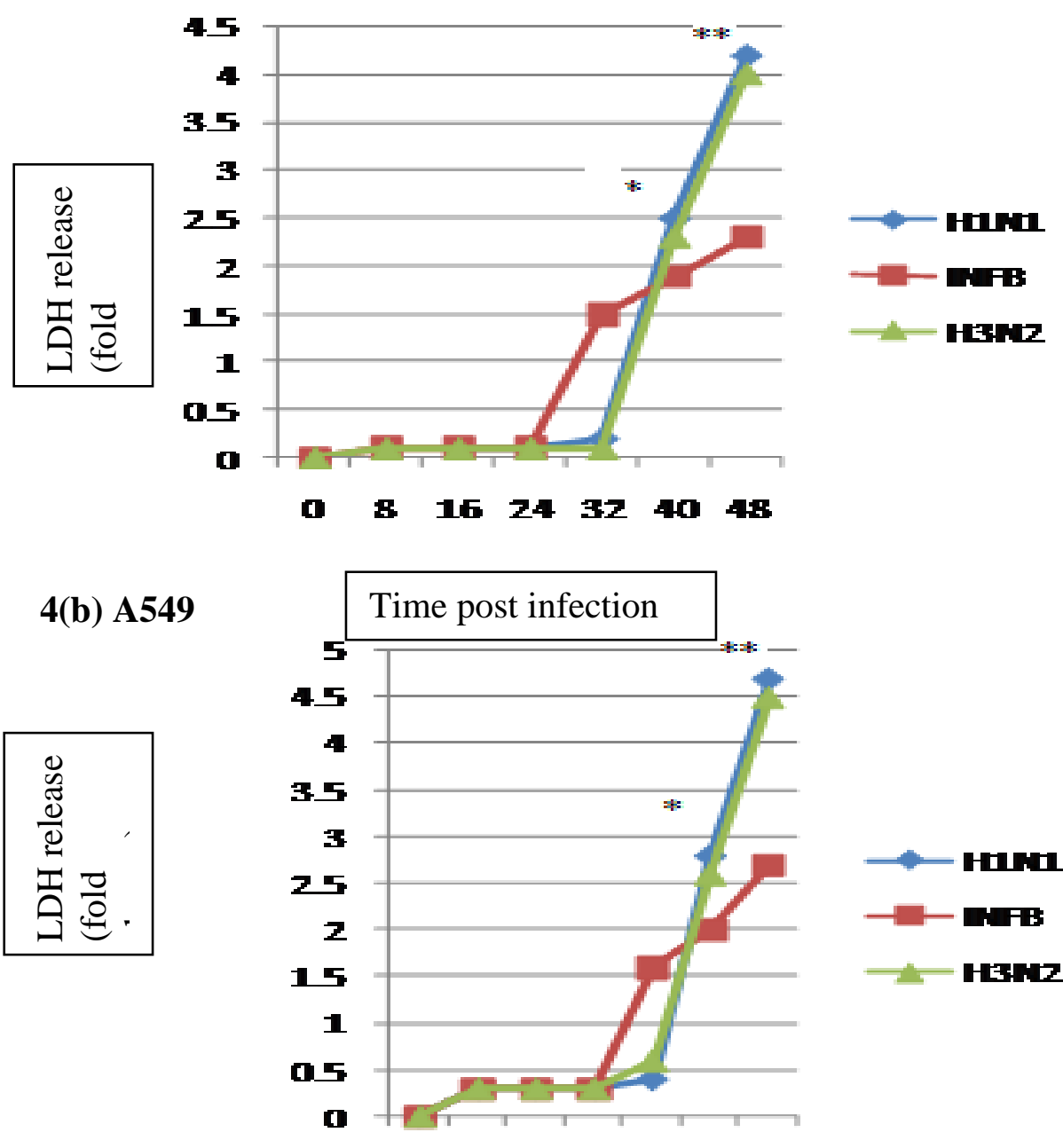

$0 \quad 31624324048$

\section{Time post infection}

Fig 4 : Flu A/Pdm H1N1 09, Flu A/H3N2 and Flu B/Yamagata viruses induce cell death and apoptosis profiles. Effects of influenza infection (MOI $1.0)$ on viability of MDCK II(4a), and A549 cells $(4 \mathrm{~b})$ were determined by LDH assay. The $*$ indicates significant differences $(\mathrm{P}<0.05)$ and $* * \mathrm{p}<$ 0.01 from the mock cells at the same time after infection. 
Table 2: Viral and cellular genes expression levels in response to H3N2 influenza virus of A549 and MDCK cells evaluated by quantitative RT-PCR at the indicated time point. Ct values were determined for CASPASES 3,8 and 9 , TNF $\alpha$, IkB $\mathrm{B}, \mathrm{BAD}, \mathrm{Mx}$, and $\beta$-actin and GPDH genes.

\begin{tabular}{|c|c|c|c|c|c|c|c|c|c|c|c|c|c|c|c|c|c|c|}
\hline \begin{tabular}{|l|}
$\mathrm{H}$ \\
3 \\
$\mathrm{~N}$ \\
2
\end{tabular} & \multicolumn{2}{|c|}{$\mathrm{IkBa}$} & \multicolumn{2}{|c|}{ BAD } & \multicolumn{2}{|c|}{ TNF } & \multicolumn{2}{|c|}{ CASPASE 9} & \multicolumn{2}{|c|}{$\begin{array}{c}\text { CASPAS } \\
\text { E } 8\end{array}$} & \multicolumn{2}{|c|}{$\begin{array}{l}\text { CASPA } \\
\text { SE3 }\end{array}$} & \multicolumn{2}{|c|}{ MXA } & \multicolumn{2}{|c|}{$\beta$ actin } & \multicolumn{2}{|c|}{ GPDH } \\
\hline $\begin{array}{l}\mathrm{M} \\
\mathrm{DC}\end{array}$ & & & & & & & & & & & & & & & & & & \\
\hline & $\begin{array}{l}\text { Moi } \\
0.1\end{array}$ & $\begin{array}{l}\text { Moi } \\
1.0\end{array}$ & $\begin{array}{l}\text { Moi } \\
0.1\end{array}$ & $\begin{array}{l}\text { Moi } \\
1.0\end{array}$ & $\begin{array}{l}\text { Moi } \\
0.1\end{array}$ & \begin{tabular}{|l} 
Moi \\
1.0
\end{tabular} & $\begin{array}{l}\text { Moi } \\
0.1\end{array}$ & $\begin{array}{l}\text { Moi } \\
1.0\end{array}$ & $\begin{array}{l}\mathrm{M} \\
\text { oi } \\
0 . \\
1\end{array}$ & $\begin{array}{l}M \\
\text { oi } \\
1 . \\
0\end{array}$ & $\begin{array}{l}\text { M } \\
\text { oi } \\
0 . \\
1\end{array}$ & $\begin{array}{l}\text { M } \\
\text { oi } \\
1 . \\
0\end{array}$ & $\begin{array}{l}\text { Mo } \\
\text { i } \\
0.1\end{array}$ & $\begin{array}{l}\text { M } \\
\text { oi } \\
1 . \\
0\end{array}$ & $\begin{array}{l}\mathrm{M} \\
\text { oi } \\
0 . \\
1\end{array}$ & $\begin{array}{l}\mathrm{M} \\
\text { oi } \\
1 . \\
0\end{array}$ & $\begin{array}{l}\text { M } \\
\text { oi } \\
0 . \\
1\end{array}$ & $\begin{array}{l}\text { M } \\
\text { oi } \\
1 . \\
0\end{array}$ \\
\hline $\begin{array}{l}16 \\
\mathrm{HI}\end{array}$ & $\begin{array}{l}22.4 \\
6\end{array}$ & $\begin{array}{l}22.7 \\
6\end{array}$ & $\begin{array}{l}16.3 \\
8\end{array}$ & $\begin{array}{l}15.8 \\
5\end{array}$ & 25 & 25.8 & 24.2 & 25.3 & 25 & 26 & 26 & $\begin{array}{l}27 \\
6\end{array}$ & 27 & 26 & $\begin{array}{l}17 \\
.2\end{array}$ & $\begin{array}{l}17 \\
.2\end{array}$ & $\begin{array}{l}22 \\
.2\end{array}$ & $\begin{array}{l}22 \\
.2\end{array}$ \\
\hline \begin{tabular}{|l|}
24 \\
$\mathrm{HI}$
\end{tabular} & $\begin{array}{l}26.5 \\
7\end{array}$ & $\begin{array}{l}26.3 \\
3\end{array}$ & $\begin{array}{l}19.7 \\
7\end{array}$ & $\begin{array}{l}20.9 \\
8\end{array}$ & 28.4 & $\begin{array}{l}28.7 \\
9\end{array}$ & 27.6 & 28.4 & 29 & 30 & $\begin{array}{l}31 \\
.2\end{array}$ & $\begin{array}{c}30 \\
.8\end{array}$ & 28 & 29 & $\begin{array}{l}17 \\
.5\end{array}$ & $\begin{array}{l}17 \\
.6\end{array}$ & $\begin{array}{l}23 \\
.6\end{array}$ & $\begin{array}{l}23 \\
.6\end{array}$ \\
\hline $\begin{array}{l}36 \\
\mathrm{HI}\end{array}$ & $\begin{array}{l}24.8 \\
2\end{array}$ & 25.2 & 18.4 & 19.9 & $\begin{array}{l}26.7 \\
2\end{array}$ & $\begin{array}{l}26.9 \\
9\end{array}$ & 26.4 & 27.0 & 27 & 27 & $\begin{array}{l}28 \\
.7\end{array}$ & $\begin{array}{l}27 \\
.4\end{array}$ & 26 & 28 & $\begin{array}{l}17 \\
.9\end{array}$ & 18 & $\begin{array}{l}23 \\
.2\end{array}$ & $\begin{array}{l}23 \\
.2\end{array}$ \\
\hline $\begin{array}{l}48 \\
\mathrm{HI}\end{array}$ & 23.2 & $\begin{array}{l}23.2 \\
2\end{array}$ & $\begin{array}{l}24.6 \\
6 \\
\end{array}$ & $\begin{array}{l}27.7 \\
5\end{array}$ & 25.9 & 25.9 & $\begin{array}{l}25.6 \\
9 \\
\end{array}$ & 27 & 26 & 26 & $\begin{array}{l}26 \\
.9 \\
\end{array}$ & $\begin{array}{l}26 \\
.4 \\
\end{array}$ & 26 & 26 & $\begin{array}{l}18 \\
.3\end{array}$ & $\begin{array}{l}18 \\
.4\end{array}$ & 23 & 23 \\
\hline $\begin{array}{l}\text { A54 } \\
9\end{array}$ & & & & & & & & & & & & & & & & & & \\
\hline $\begin{array}{l}16 \\
\mathrm{HI}\end{array}$ & 19.2 & $\begin{array}{l}19.6 \\
9\end{array}$ & 16.8 & 18.4 & 20 & 20.9 & 22.8 & 21.9 & 19 & $\begin{array}{l}20 \\
.6\end{array}$ & 21 & $\begin{array}{l}21 \\
.6 \\
\end{array}$ & 27 & 27 & $\begin{array}{l}16 \\
.9\end{array}$ & $\begin{array}{l}16 \\
.9\end{array}$ & $\begin{array}{l}20 \\
.3 \\
\end{array}$ & $\begin{array}{l}20 \\
.6\end{array}$ \\
\hline $\begin{array}{l}24 \\
\mathrm{HI}\end{array}$ & $\begin{array}{l}22.6 \\
3\end{array}$ & $\frac{22.7}{5}$ & $\begin{array}{l}17.5 \\
5\end{array}$ & $\begin{array}{l}17.6 \\
6\end{array}$ & 23 & 22.7 & 23 & 22.7 & \begin{tabular}{|l|}
23 \\
.2
\end{tabular} & $\begin{array}{l}24 \\
.1\end{array}$ & $\frac{25}{.2}$ & $\frac{25}{2}$ & 31 & $\begin{array}{l}31 \\
.6 \\
6\end{array}$ & $\begin{array}{l}17 \\
.2\end{array}$ & $\begin{array}{l}17 \\
.2\end{array}$ & $\begin{array}{l}21 \\
.0\end{array}$ & $\begin{array}{l}21 \\
.0\end{array}$ \\
\hline $\begin{array}{l}36 \\
\mathrm{HI}\end{array}$ & $\begin{array}{l}21.2 \\
5\end{array}$ & $\begin{array}{l}22.2 \\
5\end{array}$ & $\begin{array}{l}18.2 \\
2\end{array}$ & 22.5 & 24 & 22.9 & 24 & 23.6 & \begin{tabular}{|l|}
21 \\
.6 \\
5
\end{tabular} & $\begin{array}{l}21 \\
.4 \\
5\end{array}$ & 23 & 23 & $\begin{array}{l}29 . \\
4\end{array}$ & $\begin{array}{l}29 \\
.8 \\
8\end{array}$ & $\begin{array}{l}17 \\
.9\end{array}$ & $\begin{array}{l}17 \\
.8\end{array}$ & $\begin{array}{l}21 \\
.0\end{array}$ & $\begin{array}{l}21 \\
.0\end{array}$ \\
\hline $\begin{array}{l}48 \\
\mathrm{HI}\end{array}$ & $\begin{array}{l}19.3 \\
6\end{array}$ & $\begin{array}{l}20.1 \\
5\end{array}$ & 17.2 & $\begin{array}{l}17.9 \\
5\end{array}$ & 22 & 21.4 & $\begin{array}{l}21.7 \\
7\end{array}$ & 22.2 & 21 & $\begin{array}{l}19 \\
.8\end{array}$ & $\begin{array}{l}21 \\
.9\end{array}$ & $\begin{array}{l}21 \\
.8 \\
8\end{array}$ & $\begin{array}{l}27 . \\
4\end{array}$ & $\begin{array}{l}27 \\
.8 \\
9\end{array}$ & $\begin{array}{l}17 \\
.2\end{array}$ & $\begin{array}{l}17 \\
.0\end{array}$ & $\begin{array}{l}21 \\
.0\end{array}$ & $\begin{array}{l}21 \\
.0\end{array}$ \\
\hline
\end{tabular}


Table 3: Viral and cellular genes expression levels in response to influenza B virus of A549 and MDCK cells evaluated by quantitative RT-PCR at the indicated time point. Ct values were determined for CASPASES 3,8 and 9, TNF $\alpha$, IKB $\alpha$, BAD, Mx, and $\beta$-actin and GPDH genes.

\begin{tabular}{|c|c|c|c|c|c|c|c|c|c|c|c|c|c|c|c|c|c|c|}
\hline $\begin{array}{l}\text { IN } \\
\text { FB }\end{array}$ & \multicolumn{2}{|c|}{$\mathrm{IKB \alpha}$} & \multicolumn{2}{|c|}{ BAD } & \multicolumn{2}{|c|}{ TNF } & \multicolumn{2}{|c|}{ CASPASE 9} & \multicolumn{2}{|c|}{$\begin{array}{c}\text { CASPASE } \\
8\end{array}$} & \multicolumn{2}{|c|}{$\begin{array}{l}\text { CASPAS } \\
\text { E3 }\end{array}$} & \multicolumn{2}{|c|}{ MXA } & \multicolumn{2}{|c|}{$\beta$ actin } & \multicolumn{2}{|c|}{ GPDH } \\
\hline \multicolumn{19}{|c|}{$\begin{array}{l}\mathrm{MD} \\
\mathrm{CK}\end{array}$} \\
\hline & $\begin{array}{l}\text { Moi } \\
0.1\end{array}$ & $\begin{array}{l}\text { Moi } \\
1.0\end{array}$ & $\begin{array}{l}\text { Moi } \\
0.1\end{array}$ & $\begin{array}{l}\text { Moi } \\
1.0\end{array}$ & $\begin{array}{l}\text { Moi } \\
0.1\end{array}$ & $\begin{array}{l}\text { Moi } \\
1.0\end{array}$ & $\begin{array}{l}\text { Moi } \\
0.1\end{array}$ & $\begin{array}{l}\text { Moi } \\
1.0\end{array}$ & $\begin{array}{l}\mathrm{M} \\
\text { oi } \\
0.1\end{array}$ & $\begin{array}{l}\mathrm{M} \\
\text { oi } \\
1.0\end{array}$ & $\begin{array}{l}\mathrm{M} \\
\text { oi } \\
0 . \\
1\end{array}$ & $\begin{array}{l}\text { M } \\
\text { oi } \\
1 . \\
0\end{array}$ & $\begin{array}{l}\text { Mo } \\
\mathrm{i} \\
0.1\end{array}$ & $\begin{array}{l}\mathrm{M} \\
\text { oi } \\
0 . \\
1\end{array}$ & $\begin{array}{l}\mathrm{M} \\
\text { oi } \\
0 . \\
1\end{array}$ & $\begin{array}{l}\mathrm{M} \\
\text { oi } \\
1 . \\
0\end{array}$ & $\begin{array}{l}\mathrm{M} \\
\text { oi } \\
0 . \\
1\end{array}$ & $\begin{array}{l}\mathrm{M} \\
\text { oi } \\
1 . \\
0\end{array}$ \\
\hline $\begin{array}{l}16 \\
\mathrm{HI}\end{array}$ & 16 & $\begin{array}{l}16.7 \\
6\end{array}$ & $\begin{array}{l}18.3 \\
8\end{array}$ & $\begin{array}{l}18.8 \\
5\end{array}$ & 20 & 20.4 & 23.2 & 24.3 & $-*$ & $*_{-}^{\circ}$ & $\begin{array}{c}16 \\
.8\end{array}$ & $\begin{array}{c}16 \\
.6\end{array}$ & 22 & 23 & $\begin{array}{l}17 \\
.2\end{array}$ & $\begin{array}{l}17 \\
.2\end{array}$ & 22 & $\begin{array}{l}22 \\
.2\end{array}$ \\
\hline $\begin{array}{l}24 \\
\mathrm{HI}\end{array}$ & $\begin{array}{l}20.5 \\
7\end{array}$ & $\begin{array}{l}20.3 \\
3\end{array}$ & $\begin{array}{l}22.7 \\
7\end{array}$ & 22.9 & $\begin{array}{l}24.6 \\
3\end{array}$ & $\begin{array}{l}24.8 \\
9\end{array}$ & 26.6 & 27.4 & $-*$ & $-*$ & $\begin{array}{c}21 \\
.2\end{array}$ & $\begin{array}{l}20 \\
.8\end{array}$ & 26 & $\begin{array}{l}26 \\
.7\end{array}$ & $\begin{array}{l}17 \\
.6\end{array}$ & $\begin{array}{l}17 \\
.6\end{array}$ & $\begin{array}{l}23 \\
.5\end{array}$ & $\begin{array}{c}23 \\
.6\end{array}$ \\
\hline $\begin{array}{l}36 \\
\mathrm{HI}\end{array}$ & $\begin{array}{l}18.8 \\
2\end{array}$ & $\begin{array}{l}18.6 \\
3\end{array}$ & 20.4 & 20.9 & $\begin{array}{l}22.7 \\
8\end{array}$ & $\begin{array}{l}23.1 \\
6\end{array}$ & 25.4 & 26.0 & $-*$ & $-*$ & $\begin{array}{c}18 \\
.7\end{array}$ & $\begin{array}{l}17 \\
.4\end{array}$ & $\begin{array}{l}24 . \\
2\end{array}$ & $\begin{array}{c}24 \\
.5\end{array}$ & 18 & 18 & $\begin{array}{l}23 \\
.0\end{array}$ & $\begin{array}{c}23 \\
.2\end{array}$ \\
\hline $\begin{array}{l}48 \\
\mathrm{HI}\end{array}$ & 17.2 & $\begin{array}{l}17.2 \\
2\end{array}$ & $\begin{array}{l}19.6 \\
6\end{array}$ & $\begin{array}{l}19.7 \\
5\end{array}$ & 20.9 & 20.9 & 24.6 & 25.9 & -* & -* & $\begin{array}{c}16 \\
.9\end{array}$ & $\begin{array}{l}17 \\
.4\end{array}$ & $\begin{array}{l}22 . \\
7\end{array}$ & $\begin{array}{l}22 \\
.9\end{array}$ & $\begin{array}{l}18 \\
.4\end{array}$ & $\begin{array}{l}18 \\
.4\end{array}$ & $\begin{array}{l}23 \\
.1\end{array}$ & 23 \\
\hline \multicolumn{19}{|c|}{$\begin{array}{l}\text { A54 } \\
9\end{array}$} \\
\hline $\begin{array}{l}16 \\
\mathrm{HI}\end{array}$ & 18.2 & $\begin{array}{l}18.4 \\
4\end{array}$ & 19.8 & 18.4 & 19.4 & 19.9 & -* & $-*$ & $\begin{array}{l}19 . \\
8\end{array}$ & $\begin{array}{l}20 . \\
6\end{array}$ & $\begin{array}{c}15 \\
.9\end{array}$ & $\begin{array}{c}15 \\
.9\end{array}$ & 19 & 27 & $\begin{array}{l}16 \\
.9\end{array}$ & $\begin{array}{l}16 \\
.9\end{array}$ & 21 & $\begin{array}{l}20 \\
6 \\
6\end{array}$ \\
\hline $\begin{array}{l}24 \\
\mathrm{HI}\end{array}$ & $\begin{array}{l}22.6 \\
3\end{array}$ & $\begin{array}{l}22.7 \\
5\end{array}$ & $\begin{array}{l}23.5 \\
5\end{array}$ & 24.1 & 22 & 21.7 & $-*$ & $-*$ & $\begin{array}{l}22 . \\
2\end{array}$ & $\begin{array}{l}23 . \\
1\end{array}$ & $\begin{array}{c}19 \\
.2\end{array}$ & $\begin{array}{c}19 \\
.2\end{array}$ & 22 & $\begin{array}{l}22 \\
.7\end{array}$ & $\begin{array}{l}17 \\
.4\end{array}$ & $\begin{array}{l}17 \\
.2 \\
\end{array}$ & 21 & $\begin{array}{c}21 \\
.0\end{array}$ \\
\hline $\begin{array}{l}36 \\
\mathrm{HI}\end{array}$ & $\begin{array}{l}20.2 \\
5\end{array}$ & 20.6 & 21.2 & 21.7 & 21.2 & 21.9 & $-*$ & $-*$ & $\begin{array}{l}21 . \\
65\end{array}$ & $\begin{array}{l}21 . \\
45\end{array}$ & 17 & 17 & $\begin{array}{l}20 . \\
4\end{array}$ & $\begin{array}{c}20 \\
.8\end{array}$ & $\begin{array}{l}17 \\
.9\end{array}$ & $\begin{array}{l}17 \\
.8\end{array}$ & $\begin{array}{l}21 \\
.3\end{array}$ & $\begin{array}{c}21 \\
.0\end{array}$ \\
\hline $\begin{array}{l}48 \\
\mathrm{HI}\end{array}$ & 18.9 & $\begin{array}{l}19.1 \\
5\end{array}$ & 20 & 20 & 20.7 & 20.2 & $-*$ & -* & $\begin{array}{l}21 . \\
4\end{array}$ & $\begin{array}{l}19 . \\
6\end{array}$ & $\begin{array}{c}16 \\
.9\end{array}$ & $\begin{array}{c}16 \\
.4\end{array}$ & $\begin{array}{l}19 . \\
4\end{array}$ & $\begin{array}{l}19 \\
.6\end{array}$ & $\begin{array}{l}17 \\
.2\end{array}$ & $\begin{array}{c}17 \\
.0\end{array}$ & $\begin{array}{l}21 \\
.1\end{array}$ & $\begin{array}{c}21 \\
.0\end{array}$ \\
\hline
\end{tabular}

Table 4: Viral and cellular genes expression levels in response to H1N1 influenza virus of A549 and MDCK cells evaluated by quantitative RT-PCR at the indicated time point. Ct values were determined for CASPASES 3,8 and 9, TNF $\alpha$, IkB $\mathrm{B}$, BAD, Mx, and $\beta$-actin and GPDH genes. 


\begin{tabular}{|c|c|c|c|c|c|c|c|c|c|c|c|c|c|c|c|c|c|c|}
\hline $\begin{array}{l}\mathrm{H} \\
1 \\
\mathrm{~N} \\
1\end{array}$ & \multicolumn{2}{|c|}{$\mathrm{IKB \alpha}$} & \multicolumn{2}{|c|}{ BAD } & \multicolumn{2}{|c|}{ TNF } & \multicolumn{2}{|c|}{$\begin{array}{c}\text { CASPASE } \\
9\end{array}$} & \multicolumn{2}{|c|}{$\begin{array}{c}\text { CASPA } \\
\text { SE } 8\end{array}$} & \multicolumn{2}{|c|}{$\begin{array}{l}\text { CASP } \\
\text { ASE3 }\end{array}$} & \multicolumn{2}{|c|}{ MXA } & \multicolumn{2}{|c|}{$\beta$ actin } & \multicolumn{2}{|c|}{ GPDH } \\
\hline $\begin{array}{l}\mathrm{M} \\
\mathrm{DC}\end{array}$ & & & & & & & & & & & & & & & & & & \\
\hline & $\begin{array}{l}\text { Moi } \\
0.1\end{array}$ & $\begin{array}{l}\text { Moi } \\
1.0\end{array}$ & $\begin{array}{l}\text { Moi } \\
0.1\end{array}$ & $\begin{array}{l}\text { Moi } \\
1.0\end{array}$ & $\begin{array}{l}\text { Moi } \\
0.1\end{array}$ & $\begin{array}{l}\text { Moi } \\
1.0\end{array}$ & $\begin{array}{l}\text { Moi } \\
0.1\end{array}$ & $\begin{array}{l}\text { Moi } \\
1.0\end{array}$ & $\begin{array}{l}\text { M } \\
\text { oi } \\
0 . \\
1\end{array}$ & $\begin{array}{l}\text { M } \\
\text { oi } \\
1 . \\
0\end{array}$ & $\begin{array}{l}\text { M } \\
\text { oi } \\
0 . \\
1\end{array}$ & $\begin{array}{l}\text { M } \\
\text { oi } \\
1 . \\
0\end{array}$ & $\begin{array}{l}\text { M } \\
\text { oi } \\
0 . \\
1\end{array}$ & $\begin{array}{l}\text { M } \\
\text { oi } \\
1 . \\
0\end{array}$ & $\begin{array}{l}\text { M } \\
\text { oi } \\
0 . \\
1\end{array}$ & $\begin{array}{l}\text { M } \\
\text { oi } \\
1 . \\
0\end{array}$ & $\begin{array}{l}\mathrm{M} \\
\text { oi } \\
0 . \\
1\end{array}$ & $\begin{array}{l}\text { M } \\
\text { oi } \\
1 . \\
0\end{array}$ \\
\hline $\begin{array}{l}16 \\
\mathrm{H} \\
\mathrm{I}\end{array}$ & 18.9 & 20 & 21.6 & 21.8 & 22 & 22 & 20 & 20 & $\begin{array}{l}22 \\
.6\end{array}$ & 23 & 22 & 22 & $\begin{array}{l}16 \\
.5\end{array}$ & $\begin{array}{l}16 \\
.9\end{array}$ & $\begin{array}{l}17 \\
.2\end{array}$ & $\begin{array}{l}17 \\
.2\end{array}$ & $\begin{array}{l}22 \\
.2\end{array}$ & $\begin{array}{l}22 \\
.2\end{array}$ \\
\hline $\begin{array}{l}24 \\
\mathrm{H} \\
\mathrm{I}\end{array}$ & 21 & 21 & 23.8 & 24.2 & 24 & 24.9 & 25.4 & 24.6 & $\begin{array}{l}25 \\
.2\end{array}$ & $\begin{array}{l}24 \\
.6\end{array}$ & 26 & 26 & 20 & $\begin{array}{l}20 \\
.8\end{array}$ & $\begin{array}{l}17 \\
.6\end{array}$ & $\begin{array}{l}17 \\
.6\end{array}$ & $\begin{array}{l}23 \\
.6\end{array}$ & $\begin{array}{l}23 \\
.6\end{array}$ \\
\hline $\begin{array}{l}36 \\
\mathrm{H} \\
\mathrm{I}\end{array}$ & 20 & 19 & 21.8 & 22.2 & 22.6 & 22.4 & 23 & 23.6 & 23 & 23 & 24 & $\begin{array}{l}24 \\
.4\end{array}$ & $\begin{array}{l}18 \\
.4\end{array}$ & $\begin{array}{l}18 \\
.6\end{array}$ & 18 & 18 & $\begin{array}{l}23 \\
.2\end{array}$ & $\begin{array}{l}23 \\
.2\end{array}$ \\
\hline $\begin{array}{l}48 \\
\mathrm{H} \\
\mathrm{I}\end{array}$ & 18.9 & 18.6 & $\begin{array}{l}21.7 \\
5\end{array}$ & 21.9 & 22.9 & $\begin{array}{l}22.8 \\
8\end{array}$ & 21.3 & 21.6 & $\begin{array}{l}22 \\
.9\end{array}$ & $\begin{array}{l}23 \\
.3\end{array}$ & 23 & $\begin{array}{l}23 \\
.9\end{array}$ & $\begin{array}{l}18 \\
.0\end{array}$ & $\begin{array}{l}21 \\
.7\end{array}$ & $\begin{array}{l}18 \\
.4\end{array}$ & $\begin{array}{l}18 \\
.4\end{array}$ & 23 & 23 \\
\hline $\begin{array}{l}\text { A5 } \\
49\end{array}$ & & & & & & & & & & & & & & & & & & \\
\hline $\begin{array}{l}16 \\
\mathrm{H} \\
\mathrm{I}\end{array}$ & 19.6 & 18.7 & $\begin{array}{l}16.8 \\
2\end{array}$ & 17.1 & 20.7 & $\begin{array}{l}20.8 \\
8\end{array}$ & 21.6 & 21.2 & $\begin{array}{l}19 \\
.4\end{array}$ & $\begin{array}{l}19 \\
.8\end{array}$ & 18 & 17 & $\begin{array}{l}18 \\
.2\end{array}$ & $\begin{array}{l}29 \\
.4\end{array}$ & 17 & $\begin{array}{l}16 \\
.9\end{array}$ & $\begin{array}{l}20 \\
.7\end{array}$ & $\begin{array}{l}20 \\
.6 \\
6\end{array}$ \\
\hline $\begin{array}{l}24 \\
\mathrm{H} \\
\mathrm{I}\end{array}$ & 23 & 23.8 & 19.4 & 19.6 & $\begin{array}{l}21.8 \\
9\end{array}$ & $\begin{array}{l}22.2 \\
5\end{array}$ & 26.7 & 26.8 & 22 & 23 & 20 & 20 & 21 & $\begin{array}{l}21 \\
.3\end{array}$ & $\begin{array}{l}17 \\
.2\end{array}$ & $\begin{array}{l}17 \\
.2\end{array}$ & 21 & 21 \\
\hline $\begin{array}{l}36 \\
\mathrm{H} \\
\mathrm{I}\end{array}$ & 22 & $\begin{array}{l}21.9 \\
8\end{array}$ & 18.3 & 18.7 & 21.2 & 21.3 & 24.0 & 24.2 & $\begin{array}{l}21 \\
.8\end{array}$ & $\begin{array}{l}21 \\
.9\end{array}$ & $\begin{array}{l}19 \\
.2\end{array}$ & $\begin{array}{l}19 \\
.8\end{array}$ & $\begin{array}{l}20 \\
.4\end{array}$ & $\begin{array}{l}20 \\
.6\end{array}$ & $\begin{array}{l}17 \\
.8\end{array}$ & $\begin{array}{l}17 \\
.8\end{array}$ & 21 & $\begin{array}{l}21 \\
.0\end{array}$ \\
\hline $\begin{array}{l}48 \\
\mathrm{H} \\
\mathrm{I}\end{array}$ & $\begin{array}{l}20.4 \\
5\end{array}$ & 19.2 & $\begin{array}{l}17.6 \\
6\end{array}$ & 18.2 & 20.9 & 20.9 & $\begin{array}{l}21.8 \\
1\end{array}$ & 21.8 & $\begin{array}{l}20 \\
.8\end{array}$ & $\begin{array}{l}20 \\
.8\end{array}$ & $\begin{array}{l}17 \\
.6\end{array}$ & $\begin{array}{l}18 \\
.2\end{array}$ & $\begin{array}{l}19 \\
.2\end{array}$ & $\begin{array}{l}19 \\
.8\end{array}$ & 17 & $\begin{array}{l}17 \\
.0\end{array}$ & 21 & $\begin{array}{l}21 \\
.0\end{array}$ \\
\hline
\end{tabular}

